\title{
Morphological and functional study of the marginal sphincter of the sea anemones Phymactis clematis and Aulactinia marplatensis from intertidal of Mar del Plata, Argentina
}

\author{
Elvira A. González Oliveira ${ }^{1}$, Darlo Luis Patronelli ${ }^{1} \&$ Mauricio O. Zamponi ${ }^{2}$
}

1. Departamento de Biología, Facultad de Ciencias Exactas y Naturales, Universidad Nacional de Mar del Plata, Dean Funes 3250, Mar del Plata, Buenos Aires, Argentina. (golivera@mdp.edu.ar)

2. Departamento de Ciencias Marinas, Universidad Nacional de Mar del Plata, Dean Funes 3250, Mar del Plata, Buenos Aires, Argentina

\begin{abstract}
It was made the characterization of marginal sphincter to the species Phymactis clematis (Drayton in Dana, 1849) and Aulactinia marplatensis (Zamponi, 1977), from intertidal ecosystem through their morphogical and functional study. The species $P$. clematis has a circumscript sphincter of palmate type. This muscle is constituted by a mesogloeal axis and several mesogloeal subaxes. Axis as well as subaxes give a support to the endoderm which border is smooth. Aulactinia marplatensis has a circunscript sphincter pinnate type. The axis has a truncated cone shape while in P. clematis the shape is cylindrical on its origin and it is bifurcated at the end. Both species experiments were carried out using the isolated muscles. They were stimulated at increasing $\mathrm{KCl}$ concentrations ranging from 20 to $200 \mathrm{mM}$. The results were analysed in the form of dose-response curves expressed in tension in grams force vs concentration. Contractil force increases in a sigmoid form to increasing $\mathrm{KCl}$ concentrations. The correlation between morphology and function and the differences shown in both species would be related to their intertidal distribution.
\end{abstract}

KEYWORDS. Actiniaria, marginal sphincter, morphology, contractility.

RESUMEN. Estudio morfológico y funcional del esfínter marginal de las anémonas de mar Phymactis clematis y Aulactinia marplatensis del intermareal de Mar del Plata, Argentina. Se realizó la caracterización de las anémonas de mar Phymactis clematis (Drayton in Dana, 1849) y Aulactinia marplatensis (Zamponi, 1977) del ecosistema intermareal mediante estudio morfológico y funcional. La especie $P$. clematis tiene un esfínter circunscripto de tipo palmado. Este músculo está constituido por un eje mesogloeal y varios subejes mesogloeales. Tanto el eje como los subejes dan soporte al endodermo cuyo borde es liso. La especie A. marplatensis tiene un esfínter circunscripto de tipo pinnado. El eje tiene forma de cono truncado mientras que en $P$. clematis es cilíndrico en su origen bifurcándose en su parte final. Los experimentos fueron llevados a cabo usando el músculo aislado de ambas especies. Estos fueron estimulados a concentraciones crecientes de $\mathrm{KCl}$ en un rango de 20 a $200 \mathrm{mM}$. Los resultados fueron analizados mediante curvas dosisrespuesta expresados en tensión en gramos fuerza vs concentración. La fuerza contráctil se incrementó en forma sigmoidea. La correlación entre la morfología y función y las diferencias mostradas en ambas especies podrían estar relacionadas con su distribución en el intertidal.

PALABRAS CLAVE. Actiniaria, esfínter marginal, morfología, contractilidad.

The column of sea anemone is constituted of muscle fibers and inmediately or a short distance below the margin, the circular muscle sheet is concentrated into a special band: the marginal sphincter (STEPHENSON, 1928). This structure presents characteristics of smooth muscle (PAtronelli et al., 1998). The sphincter closes the aperture at the top of the column when the disc and tentacles have been retracted. According to the disposition of mesogloeal axis and subaxes the sphincter can be classified as circumscript, circumscript-diffuse or diffuse (MANUEL, 1981). These morphological types may present structural and physiological differences depending on the species located in intertidal or depth environment (Patronelli et al., 2004). In the intertidal ecosystem of Mar del Plata (Argentina), sea anemones are distributed in protected, partially protected or exposed areas. The different conditions in these areas such as pressure of the water column or dashing waves promote different responses in the sphincter (PATRONELli et al., 1987).

In Mar del Plata coast two species like Phymactis clematis (Drayton in Dana, 1849) and Aulactinia marplatensis (Zamponi, 1977) occur widely with a great resistance to dominant conditions (ACUÑA et al., 1995, 1998).
The aim of this work is to make a comparative study of the marginal sphincter of both species by morphological and functional analysis.

\section{MATERIAL AND METHODS}

Specimens of the sea anemones Phymactis clematis and Aulactinia marplatensis, were collected from the middle littoral in the rocky zone of Punta Cantera, Mar del Plata $\left(38^{\circ} 05^{\prime} \mathrm{S}\right.$ and $\left.57^{\circ} 38^{\prime} \mathrm{W}\right)$, Argentina. The samples, all around the same size $(30 \mathrm{~mm}$ in basal diameter), to avoid another variable, were caught in autumn-winter, period whereon the responses are optimal to mechanical stimuli, discarding those specimens with typical spawning position (PATRONELLI et al., 2002). Both species were collected in the same area under the same environmental conditions and in different positions on the substrate. Aulactinia marplatensis is distributed on the vertical walls on the rocks, unlike $P$. clematis whose distribution is extended over plane and horizontal hollows. The organisms were maintained at room temperature in an aquarium with decanted and aerated sea water. They were used between one and seven days after collection. 
Morphological study. The sphincter analysis was made by dissection techniques through longitudinal plane of the organism and it was placed in a Petri dish with fixed solution (formaldehyde solution neutralizated $40 \%$ or absolute alcoholic solution). The sphincter was observed upon stereoscopic microscope; by objectives of different resolutions the following meristic dates were measured: length and width of sphincter, of mesogloeal axis and mesogloeal subaxes.

Physiological study. Sphincter extraction and preparation were carried out according to the techniques described by Patronelli et al., 1987. The variations of tension were measured by a force transducer connected to a polygraph. The muscles were stimulated at different $\mathrm{KCl}$ concentrations (20, $40,60,80,100,120,140,160,180$ and $200 \mathrm{mM}$ ) and their responses were analysed in the form of dose-response curves expressed in tension in grams force (gr) vs concentration. Data are presented as average values \pm standard error of experiments. Statistical analysis was performed using the Student's t test. $P$ values $<0.05$ were considered statistically different.

\section{RESULTS}

Morphological study. The species $P$. clematis has a circumscript sphincter of palmate type (Fig. 1) which is between 1.06 to $1.67 \mathrm{~mm}$ long and between 0.76 to $1.21 \mathrm{~mm}$ wide. This muscle is constituted by a mesogloeal axis and several mesogloeal subaxes. Axis as well as subaxes give a support to the endoderm which border is smooth. The mesogloeal axis is between 0.30 to $1.06 \mathrm{~mm}$ long and between 0.15 to 0.60 $\mathrm{mm}$ wide. It is possible to count a number of more than 5 subaxes (6-8) which dimensions are between 0.07 to $0.91 \mathrm{~mm}$ long and 0.07 to $0.30 \mathrm{~mm}$ wide. The species $A$. marplatensis has a circumscript sphincter pinnate type (Fig. 2) which is between 1.21 to $1.76 \mathrm{~mm}$ long and between 1.06 to $1.36 \mathrm{~mm}$ wide. This muscle is constituted by a mesogloeal axis and many subaxes. Axis and subaxes give a support to endoderm of sphincter which border is folded. The mesogloeal axis is 0.30 to $0.76 \mathrm{~mm}$ long while its width is between 0.60 to $0.91 \mathrm{~mm}(\mathrm{n}=25)$. This axis has a truncated cone shape while in P. clematis the shape is cylindrical on its origin and bifurcated at the end. The mesogloeal subaxes are numerous which number is more than 9 and their dimensions are between 0.45 to $1.21 \mathrm{~mm}$ long and $0.15 \mathrm{~mm}$ wide $(\mathrm{n}=25)$.

Physiological study. Contractil force increases in a sigmoid form to increasing $\mathrm{KCl}$ concentrations (Fig. 3, 4). In P. clematis the maximal developed force obtained with $200 \mathrm{mM} \mathrm{KCl}$ was $2.68 \mathrm{gr} \pm 0.20 \mathrm{gr}(\mathrm{n}=22)$. In $A$. marplatensis maximal response reached was 1.33 gr $\pm 0.24 \mathrm{gr}(\mathrm{n}=20)$ obtained with $180 \mathrm{mM} \mathrm{KCl}$ (Fig. 5). With $200 \mathrm{mM} \mathrm{KCl}$ the response was minor which value was $1.04 \mathrm{gr} \pm 0.10 \mathrm{gr}(\mathrm{p}<0.01)$. The contraction was more sustained and the relaxation period was longer.

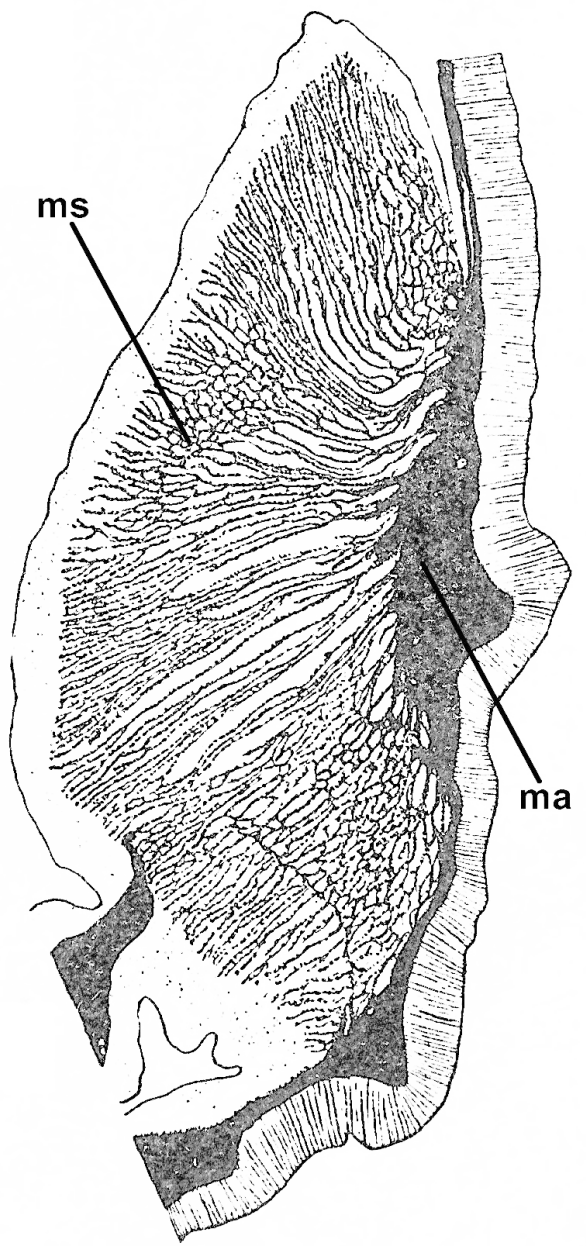

Figure 1. Circumscript sphincter of palmate type of Phymactis clematis (Drayton in Dana, 1849) (ma, mesogloeal axis; ms, mesogloeal subaxis)

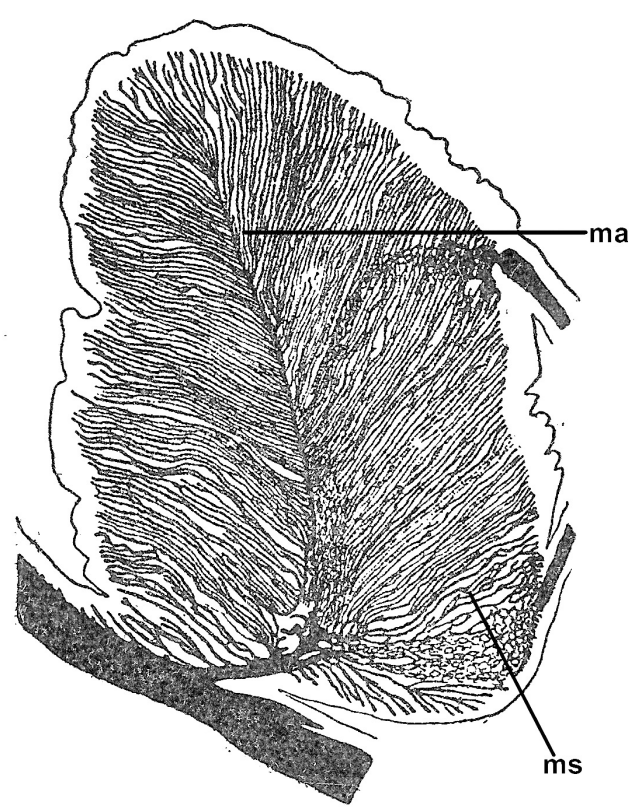

Figure 2. Circumscript sphincter of pinnate type of Aulactinia marplatensis (Zamponi, 1977) (ma, mesogloeal axis; ms, mesogloeal subaxis. 


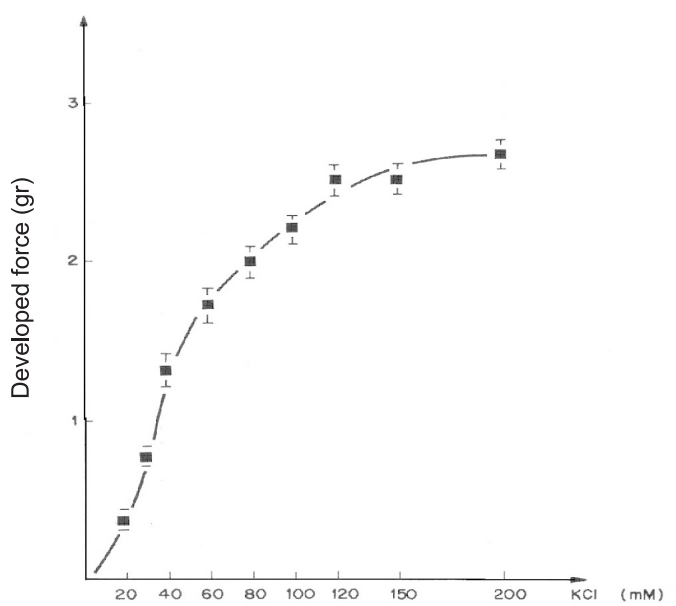

Figure 3. Dose-response curves to increasing concentrations of $\mathrm{KCl}$ $(\mathrm{mM})$ in the marginal sphincter of Phymactis clematis (Drayton in Dana, 1849) (bars represent standard error; gr, grams force; $n=22$ ).

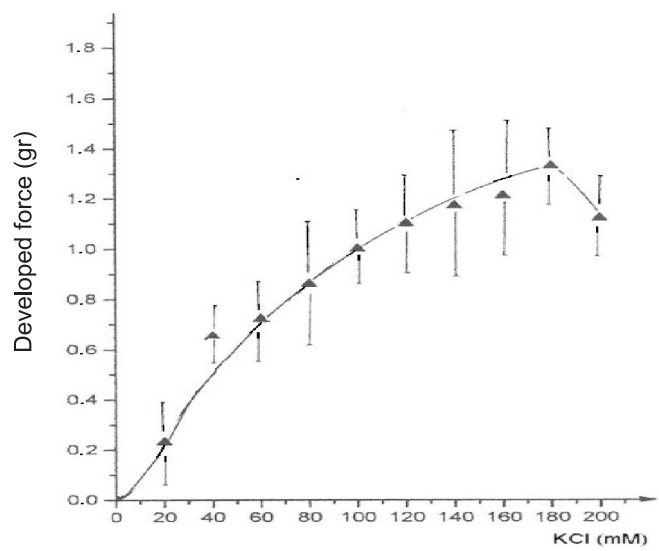

Figure 4. Dose-response curves to increasing concentrations of $\mathrm{KCl}$ $(\mathrm{mM})$ in the marginal sphincter of Aulactinia marplatensis (Zamponi, 1977) (bars represent standard error; gr, grams force; $n=20$ ).

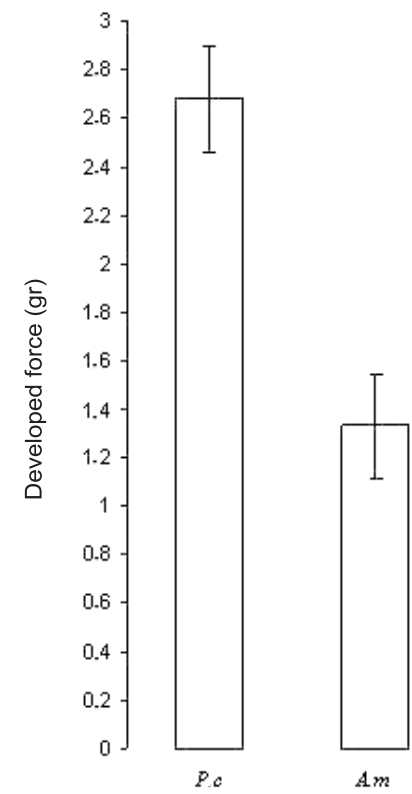

Figure 5. Maximal developed force obtained by stimulation with $200 \mathrm{mM} \mathrm{KCl}$ in Phymactis clematis (Drayton in Dana, 1849) (Pc) and $180 \mathrm{mM} \mathrm{KCl}$ in Aulactinia marplatensis (Zamponi, 1977) (Am) (bars represent standard error; gr, grams force).

\section{DISCUSSION}

The species Phymactis clematis has a smooth edge sphincter of the circumscript type, which presents constant physiological activity even if it is exposed to environmental dissecation (PATRONELli et al., 1999). Aulactinia marplatensis is found in the same study area and its sphincter presents folded edges, making a stronger structure. This morphological adaptation might be related to the localization of the species since that it is distributed on the vertical walls on the rocks, unlike $P$. clematis whose distribution is extended over plane and horizontal hollows where pressure of water is secondrate.

The analysis of sphincter contractility in both species, showed that $P$. clematis developed a higher contractile force than A. marplatensis for all $\mathrm{KCl}$ concentrations. The contractile force to $200 \mathrm{mM} \mathrm{KCl}$ was minor. This event might be related to the higher depolarization which leads to decreasing calcium ions influx, because these ions positively charge the intracellular medium repulsing more calcium ions from entering (PATRONELli et al., 2000).

Comparing sphincters of both species, morphological and functional differences were found, which might be related with their distribution in intertidal. Sphincters of $P$. clematis populations distributed in exposed areas present great differences compared to specimens from protected environments. The ones which comes from exposed environments have developed sphincters adapted to resist the continuous dashing of waves. Physiological studies correlated well with morphological observations (PAtronelli et al., 1987).

Instead, in A. marplatensis there was no correlation between morphology and function in the sphincters, as it was expected to obtain a higher contractile force, because these are stronger and have a pinnate disposition. These results suggest that $A$. marplatensis, due to its localization is subjected to direct wave impact, and its sphincter instead of developing a higher contractile force than in P. clematis uses, as an adaptative strategy, a sustained contraction and a longer relaxation.

As is it described for molluscan smooth muscles, the sphincter maintains a stretch-resistance state for long periods. This phenomenon suggests us that contraction of this smooth muscle produces a "catch" tension. This property is present for the so called "paramyosine muscles" (KRYVI, 1975) among which may be included these sphincters because under biochemical analysis in our laboratory, we have identified a protein with a molecular weight of $106 \mathrm{KDa}$ (data non published) which might correspond to paramyosine. This protein is typical in the thick filament of invertebrates. The sphincter of $A$. marplatensis might present more quantity of this protein than in P. clematis, which would allow it to combine the ability to provide relatively free movement activity and a firm position for sustained periods.

Acknowledgments. The authors wish to thank to $\mathrm{Mr}$. Juan Martín Patronelli for his technical assistance. This study was made with a financial support by the State University of Mar del Plata. Project 15/E 309. 


\section{REFERENCES}

Acuña, F. \& Zamponi, M. O. 1995. Ecología de anémonas intermareales. Densidad, dispersión y autoecología de Phymactis clematis Dana, 1849 (Anthozoa:Actiniaria). Ciencias Marinas 21(1):1-12.

1998. Estructura poblacional de Aulactinia marplatensis (Zamponi, 1977) y Aulactinia Reynaudi (Milne-Edwards, 1857) (Actiniaria, Actiniidae) en Argentina. Biociências 6(2): $13-33$

Kryvi, H. 1975. Paramyosin muscle cells interposed between longitudinal muscles and the cartilagenous skeleton of Sabella penicillum (Annelida). Protoplasma 84:257-272.

Manuel, R. L. 1981. British Anthozoa. Synopses of the British Fauna. London, Academic. 241p.

Patronelli, D. L.; González Olivera, E.; Panzeri, A.; Zabaleta, G. \& Zabaleta, A. 1999. Respuesta contráctil del esfínter marginal de la anémona Phymactis clematis (Actiniaria): Efecto de diferentes iones. Biociências 7(2):25-41.

Patronelli, D. L.; González Olivera, E. \& Zamponi, M. O. 2004 Contractile response of sea anemones (Anthozoa:Actiniaria) from subtidal environment of Mar del Plata Argentina). Revista Real Academia Galega de Ciencias 23:95-104.
Patronelli, D. L. Méndez, P. \& González Olivera, E. 2000. Calcio y calmodulina en el mecanismo contráctil del esfínter margina de la anémona Phymactis clematis (Actiniaria). Biociências $8(2): 19-32$.

2002. Contribution to the study of contraction strength of the marginal sphincter of the sea anemone Phymactis clematis (Actiniaria). Biociências 10(1):35-42.

Patronelli, D. L.; Petcoff, G. M. \& González Olivera, E. 1998. Estudio histofisiológico comparativo del esfínter marginal de Phymactis clematis (Coelenterata:Actiniaria) de diferentes ambientes. Biociências 6(1):67-78.

Patronelli, D. L.; Zamponi, M.; Bustos, A. \& Vega, F. 1987. Morphological and physiological adaptations in the marginal sphincter of anemone Phymactis clematis Dana, 1849, from different environments. Comparative Biochemistry and Physiology 88(2):337-340.

Stephenson, T. A. 1928. The British sea anemones. London, The Ray Society. v.1, 148p.

ZAmponi, M. O. 1977. La anemonofauna de Mar del Plata y localidades vecinas. I. Las anémonas Boloceroidaria y Endomyaria (Coelenterata:Actiniaria). Neotropica 23(70): 137-153.

Recebido em maio de 2008. Aceito em dezembro de 2008. ISSN 0073-4721

Artigo disponível em: www.scielo.br/isz 